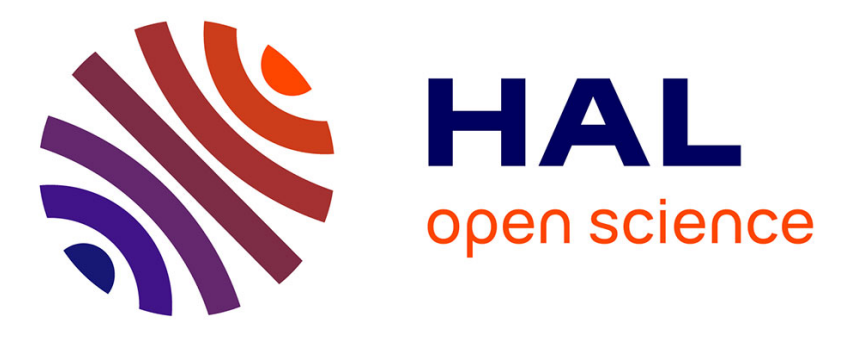

\title{
Non-Aqueous Li-Based Redox Flow Batteries
}

Stephane Hamelet, Théodore Tzedakis, Jean- Bernard Leriche, Sébastien Sailler, Dominique Larcher, Pierre-Louis Taberna, Patrice Simon, Jean-marie Tarascon

\section{- To cite this version:}

Stephane Hamelet, Théodore Tzedakis, Jean- Bernard Leriche, Sébastien Sailler, Dominique Larcher, et al.. Non-Aqueous Li-Based Redox Flow Batteries. Journal of The Electrochemical Society, 2012, vol. 159 ( $\left.\mathrm{n}^{\circ} 8\right)$, pp.A1360-A1367. 10.1149/2.071208jes . hal-01153121

\section{HAL Id: hal-01153121 \\ https://hal.science/hal-01153121}

Submitted on 19 May 2015

HAL is a multi-disciplinary open access archive for the deposit and dissemination of scientific research documents, whether they are published or not. The documents may come from teaching and research institutions in France or abroad, or from public or private research centers.
L'archive ouverte pluridisciplinaire HAL, est destinée au dépôt et à la diffusion de documents scientifiques de niveau recherche, publiés ou non, émanant des établissements d'enseignement et de recherche français ou étrangers, des laboratoires publics ou privés. 


\section{Open Archive TOULOUSE Archive Ouverte (OATAO)}

OATAO is an open access repository that collects the work of Toulouse researchers and makes it freely available over the web where possible.

This is an author-deposited version published in : http://oatao.univ-toulouse.fr/ Eprints ID : 13892

To link to this article : DOI:10.1149/2.071208jes

URL : http://dx.doi.org/10.1149/2.071208jes

\section{To cite this version :}

Hamelet, Stephane and Tzedakis, Theodore and Leriche, JeanBernard and Sailler, Sébastien and Larcher, Dominique and Taberna, Pierre-Louis and Simon, Patrice and Tarascon, Jean-Marie Non-Aqueous Li-Based Redox Flow Batteries. (2012) Journal of The Electrochemical Society, vol. 159 (n 8). A1360-A1367. ISSN 0013-4651

Any correspondance concerning this service should be sent to the repository administrator: staff-oatao@ listes-diff.inp-toulouse.fr 


\title{
Non-Aqueous Li-Based Redox Flow Batteries
}

\author{
S. Hamelet, ${ }^{a, b}$ T. Tzedakis, ${ }^{\text {b,c }}$ J.-B. Leriche, ${ }^{\text {a,b }}$ S. Sailler, ${ }^{\text {,,c }}$ D. Larcher, ${ }^{\text {a,b }}$ P.-L. Taberna, ${ }^{\text {b,d }}$ \\ P. Simon,, ,c,* and J.-M. Tarascon ${ }^{\mathrm{a}, \mathrm{b}, \mathrm{z}}$ \\ ${ }^{a}$ Laboratoire de Réactivité et Chimie des Solides, CNRS UMR 6007, Université de Picardie Jules Verne, \\ 80039 Amiens Cedex 9, France \\ ${ }^{b}$ Réseau sur le Stockage Electrochimique de l'Energie RS2E - FR3459 CNRS, France \\ ${ }^{c}$ Laboratoire de Génie Chimique, Porte 126 Bât 2RI, Université Paul Sabatier, 31062 Toulouse Cedex 9 , \\ France \\ ${ }^{d}$ Université Paul Sabatier, CIRIMAT UMR CNRS 5085, 31062 Toulouse Cedex 4, France
}

\begin{abstract}
Redox flow batteries have gained renewed interest for grid storage applications. This work focuses on the effect of various chemical/physical parameters on the performance of the $\mathrm{LiFePO}_{4} / \mathrm{LiPF}_{6} \mathrm{EC}-\mathrm{DMC} / \mathrm{Li}$ redox flow system. A methodical study of the influence of the content of active material and of the flow rate, coupled with electrochemical and hydrodynamic characterizations, have been carried out in order to better understand the various 'migration' and 'diffusion' limitations, as well as to try to overcome their effects. As a result, power density performances higher than $328 \mathrm{~mW} \cdot \mathrm{cm}^{-2}$ at $104 \mathrm{~mA} . \mathrm{cm}^{-2}$ were achieved and the feasibility of reaching energy density of $50 \mathrm{Wh} \cdot \mathrm{kg}^{-1}$ demonstrated.
\end{abstract}

Both the awareness of environmental issues together with the decline of the quantity of fossil resources has conspired to accelerate research efforts in energy conversion and storage. Electrochemical energy storage systems appear as good candidates to address this challenge. Among them, Li-ion batteries, which combine the highest energy and power density, are the most attractive. They can, for example, be used in the field of transportation to limit pollution and provide primary electricity to recharge them; the electricity can be produced by $\mathrm{CO}_{2}$-free energy sources like renewable energies. Although the $\mathrm{Li}$-ion technology has conquered the field of electronic market and is well accepted, it still falls short of meeting large mass energy storage back-up dictated by solar farms or wind turbines plants, for instance. Although the high temperature $\left(300^{\circ} \mathrm{C}\right) \mathrm{Na} / \mathrm{S}$ technology was, until this year's safety incident, regarded as the stellar for such applications, the old (1970) Redox Flow Battery technology (RFB) is gaining renewed interest and presently stands as an attractive contender to $\mathrm{Na} / \mathrm{S}$. Classical RFBs differ from conventional batteries because they store electrochemical energy in two fluids, called catholyte and anolyte, rather than in solid active materials. These catholytes and anolytes flow through an electrochemical reactor that oxidizes and reduces the soluble redox active species. ${ }^{1}$ The main advantage of the RFB technology, as opposed to other battery technologies, is rooted in the fact that power and energy are uncoupled providing significant design freedom for stationary applications. ${ }^{2}$ However, most of the RFB systems involve both aqueous solvents, implying both limited voltage windows and lower concentration of active material in comparison with conventional batteries. To bypass these limitations, since 2007, Chiang and co-workers ${ }^{3-8}$ have been proposing a new concept consisting in combining the best positive attributes of batteries and RFB. They replace dissolved species used in Redox Flow Batteries by similar solid particles in suspension in $\mathrm{Li}^{+}$-containing organic electrolyte. Such a RFB configuration was shown, depending on the flow rate, to lead to great performances. More recently, to get round the non-aqueous electrolyte cost while preserving the high voltage operation, Goodenough and co-workers ${ }^{9}$ proposed the use of a catholyte made of dissolved $\mathrm{Fe}(\mathrm{CN})_{6}{ }^{3-/ 4-}$ species in aqueous media and separated from the Limetal negative electrode by a ceramic solid electrolyte membrane. In both cases the output voltages come close to $3.5 \mathrm{~V}$.

Herein, we first report a new approach which can be considered midway between the two aforementioned concepts. It consists first in preparing a suspension of nano-particles of $\mathrm{LiFePO}_{4}$ and conductive carbon additive in an organic electrolyte, and charging and discharging it at high rates versus a metallic lithium ribbon. Besides, we evaluated the performances of these two chemistries in homemade

${ }^{*}$ Electrochemical Society Active Member.

${ }^{\mathrm{z}}$ E-mail: jean-marie.tarascon@u-picardie.fr optimized electrochemical reactors so as to benchmark such systems in terms of energy density, polarization, mass-charge transfer, conversion yield/selectivity while identifying the system performances and limitations.

\section{Experimental}

A survey of various operating parameters effects such as catholyte formulation, active material, carbon additive, electrolyte content, was conducted on various homemade cell designs whose hydrodynamic behavior was studied too. For reasons of clarity, we will first report on the cell design and then consider separately the effect of each of the aforementioned parameters.

Electrochemical reactor design.- To check the influence of the reactor configuration in terms of size, flow inlets/outlets, two similar cells, denoted hereafter "initial reactor" and "filter-press reactor" were designed for this study. Their main difference is nested in the nature/shape and the size of the anodic and cathodic compartments. The global characteristics of these setups (e.g.; "initial" and "filter-press" reactors) are described in Figure 1.

In the "initial reactor" (Figure 1b), both anodic and cathodic cylindrical compartments are $6 \mathrm{~mm}$ thick. These compartments are stainless steel and act as current collectors. The cathodic one is fed by fresh suspensions which are recovered on the same side with a $30^{\circ}$ angle between inlet and outlet. A piece of Aluminum foam (provided by the "SCP" company, made by the use of a polymer template, with 0.5 $\mathrm{mm}$ average pore size) is placed inside the catholyte volume which acts as a three-dimensional current collector. On the anodic one, the $\mathrm{Li}^{0}$ ribbon is hosted by a properly dug cavity within the cell stainless steel plate. Both compartments are electrically separated with Teflon rings between which a highly porous (56\%) Celgard (ref. CG2500) polypropylene separator is placed.

For the "filter-press" cell (Figure 1c), the reactives zone are composed of two Teflon frames, adapted to the thickness of the lithium: $0.5 \mathrm{~mm}$ for the negative one and $1 \mathrm{~mm}$ thick for the positive one. While the lithium foil is around $4 \mathrm{~cm}^{2}$, the geometric accessible surface to catholytic reactive suspension circulation is around $14 \mathrm{~cm}^{2}$. The two Teflon compartments are separated by the polypropylene membrane (CG2500) and sandwiched between two $\mathrm{Cu}$ and $\mathrm{Al}$ metal plates $(0.5$ $\mathrm{mm}$ thick) acting as negative and positive current collectors, respectively. Note that a third electrode could eventually be added to the middle of each electrolytic compartment, or between them, to act as a reference/pseudo-reference electrode.

Last, two Teflon blocks, each one equipped with two tubes, are used to connect the reactor to the external suspensions tanks, with the entire device being tightly screwed between two steel plates. Each 
a)

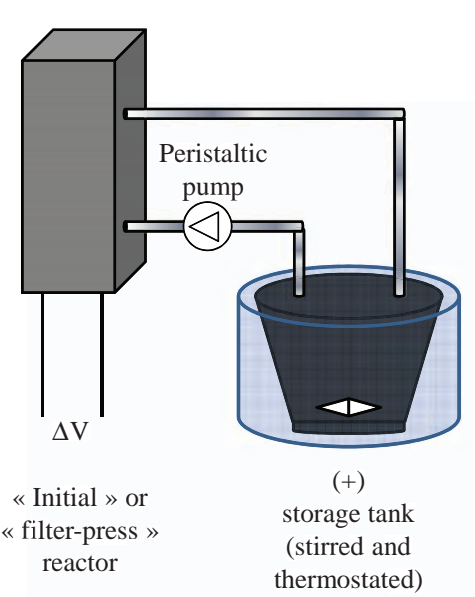

b)

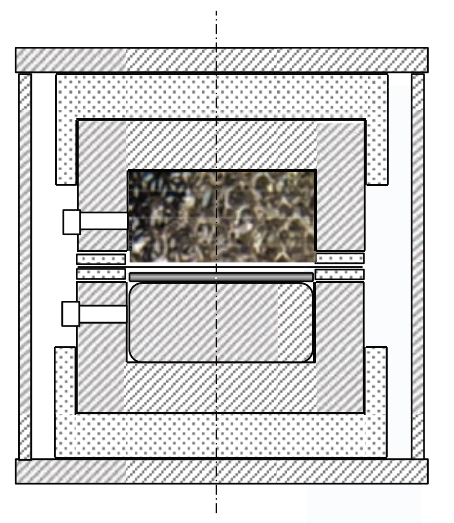

Steel plate

Teflon insulator

$6 \mathrm{~mm}$ thick steel tank

filled with $5 \mathrm{~mm} \mathrm{Al}$ foam

Teflon rings with Celgard

Steel tank with Li ribbon

Teflon insulator

Steel plate

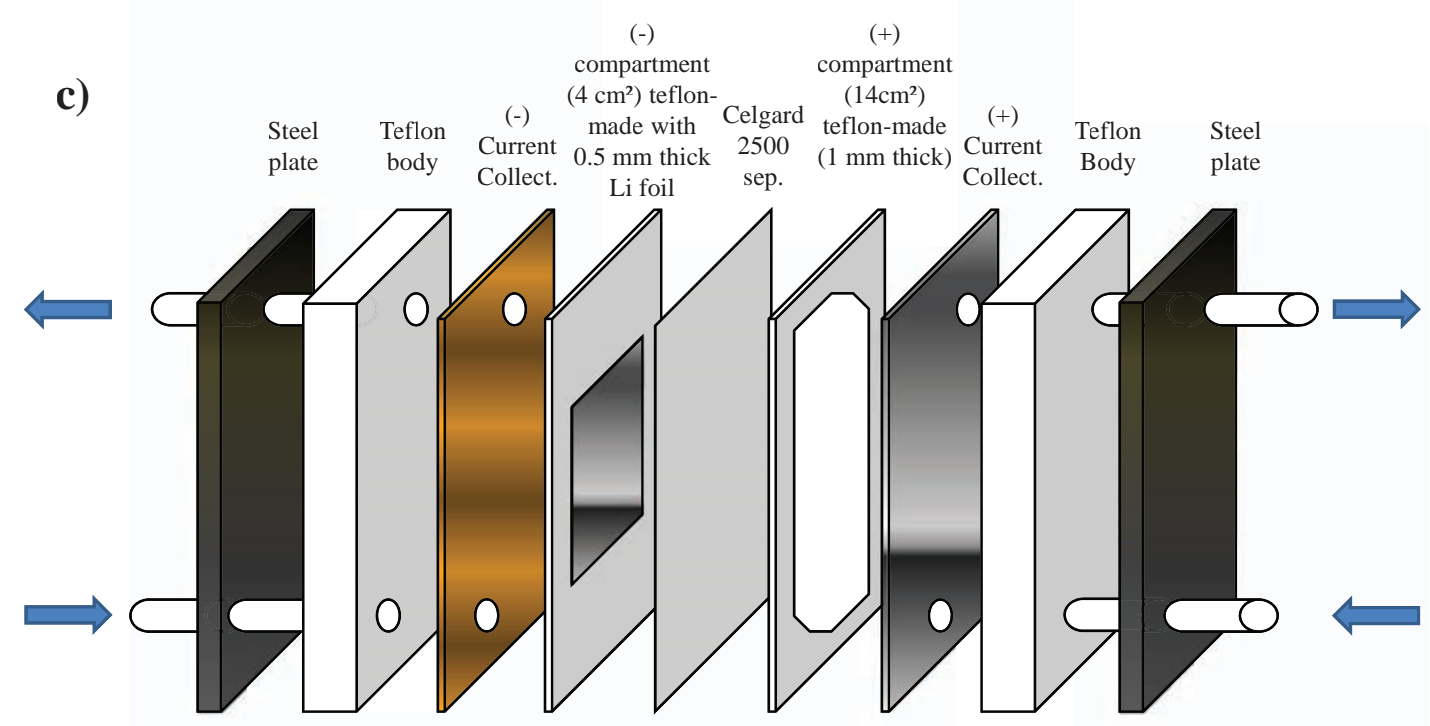

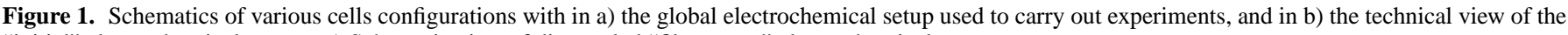
"initial" electrochemical reactor. c) Schematic view of dismantled "filter-press" electrochemical reactor.

suspension is stored in a $100 \mathrm{~mL}$ tank, magnetically stirred, kept at $20^{\circ} \mathrm{C}$, and connected to the electrochemical reactor with $5 \mathrm{~mm}$ diameter semi-rigid Teflon tubes. The entire filling of this device is done in a glove box under argon inert gas. Peristaltic pumps (Cole Parmer 7584-85, with Masterflex 77390-00 pump head) with Teflon pipes were selected to fuel both catholytes and anolytes to the electrochemical reactor because of the high chemical robustness toward various chemical components.

Suspensions of active materials.- All the suspensions reported herein were made with solutions of $1 \mathrm{M} \mathrm{LiPF}_{6}$ in ethylene carbonate (EC), and dimethyl carbonate (DMC) $(1: 1 \mathrm{w} / \mathrm{w})$ as the electrolyte (ref. LP30 provided by Merck). $\mathrm{LiFePO}_{4}$ powders consisting of 150 $\mathrm{nm}$ carbon coated $(2.5 \%$ wt. defined from TGA analysis) particles, which have a redox potential of $3.45 \mathrm{~V}$ vs. $\mathrm{Li}^{+} / \mathrm{Li}^{\circ}$, were used to prepare the catholyte solution. This powder has a B.E.T surface area of $\approx 25 \mathrm{~m}^{2} \cdot \mathrm{g}^{-1}$ and a density of $780 \mathrm{~kg} \cdot \mathrm{m}^{-3}$. Last but not least, an electronic conductive additive has to be added to both the catholyte and anolyte suspensions to improve the suspension electronic wiring in view of reaching attractive electrochemical performances.

A survey of adding various graphites, carbon blacks or carbon fibers to the aforementioned suspensions was conducted to identify the best additive in terms of electronic percolation. Among them, the
Ketjenblack (KB300, provided by AczoNobel), which consists of a mixture of spheres and fibers, having a specific area of $780 \mathrm{~m}^{2} \cdot \mathrm{g}^{-1}$ and a density of $170 \mathrm{~kg} . \mathrm{m}^{-3}$, was chosen. From simple charge/discharge polarization measurements, KB300 turns out to be more attractive than classical "Super P" (provided by Timcal), commonly used nowadays as electronic additive in Li-ion batteries. Indeed, for a fixed carbon loading, the polarization was shown to decrease significantly from $1.6 \mathrm{~V}$ to $300 \mathrm{mV}$ when $\mathrm{C}_{\mathrm{sp}}$ was replaced by $\mathrm{KB} 300$ as conducting additive.

Having identified the best carbon, further electrochemical tests were conducted on suspensions having different active material - carbon additive - electrolyte formulations. The catholytes used through the paper for capacity, energy density or power performances enhancement are listed in Table I. For sake of comparison, all the volumetric percents were calculated using the tapped density as the fastest and closest reference from the measured densities of the suspensions.

\section{Results}

Preliminary tests with the " $A$ " formulation.- Several galvanostatic charge and discharge tests were carried out on $\mathrm{LiFePO}_{4} / \mathrm{Li}$ redox flow cells operating in either static or flow modes. The first step 
Table I. Compositions (volumetric and weight percents of active material $\mathrm{LiFePO}_{4}\left(\mathrm{LFP} ; 780 \mathrm{kg.m}^{-3}\right.$ ), conductive additive Ketjenblack EC-300-J $\left(\mathrm{KB} ; 170 \mathrm{~kg} . \mathrm{m}^{-3}\right)$ and organic electrolyte (LP30)) and theoretical electrochemical performances of the various formulation/suspensions used for the catholyte.

\begin{tabular}{|c|c|c|c|c|c|c|c|c|c|c|}
\hline Form & LFP & $\mathrm{KB}$ & LP30 & \%vol LFP & $\%$ vol KB & \%vol LP30 & $\% \mathrm{~m}$ LFP & $\% \mathrm{~m} \mathrm{~KB}$ & $\mathrm{Wh} / \mathrm{kg}$ & $\mathrm{Wh} / \mathrm{L}$ \\
\hline A & $1.8 \mathrm{~g}$ & $1.8 \mathrm{~g}$ & $128 \mathrm{~g}(100 \mathrm{~mL})$ & 2.0 & 9.4 & 88.6 & 1.4 & 1.4 & 8.0 & 9.4 \\
\hline $\mathrm{B}$ & $1.8 \mathrm{~g}$ & $3.6 \mathrm{~g}$ & $128 \mathrm{~g}(100 \mathrm{~mL})$ & 1.9 & 17.2 & 81.0 & 1.4 & 2.7 & 7.9 & 8.6 \\
\hline $\mathrm{C}$ & $3.6 \mathrm{~g}$ & $1.8 \mathrm{~g}$ & $128 \mathrm{~g}(100 \mathrm{~mL})$ & 4.0 & 9.2 & 86.8 & 2.7 & 1.4 & 15.9 & 18.3 \\
\hline $\mathrm{D}$ & $3.6 \mathrm{~g}$ & $3.6 \mathrm{~g}$ & $128 \mathrm{~g}(100 \mathrm{~mL})$ & 3.7 & 16.8 & 79.5 & 2.7 & 2.7 & 15.6 & 16.8 \\
\hline E1 & $6.5 \mathrm{~g}$ & $0.5 \mathrm{~g}$ & $89.6 \mathrm{~g}(70 \mathrm{~mL})$ & 10.2 & 3.6 & 86.1 & 6.7 & 0.5 & 39.4 & 46.8 \\
\hline E2 & $6.5 \mathrm{~g}$ & $0.5 \mathrm{~g}$ & $83.2 \mathrm{~g}(65 \mathrm{~mL})$ & 10.9 & 3.9 & 85.2 & 7.2 & 0.6 & 42.2 & 49.9 \\
\hline E3 & $6.5 \mathrm{~g}$ & $0.5 \mathrm{~g}$ & $76.8 \mathrm{~g}(60 \mathrm{~mL})$ & 11.7 & 4.1 & 84.2 & 7.8 & 0.6 & 45.4 & 53.4 \\
\hline $\mathrm{E} 4$ & $6.5 \mathrm{~g}$ & $0.5 \mathrm{~g}$ & $70.4 \mathrm{~g}(55 \mathrm{~mL})$ & 12.6 & 4.4 & 83.0 & 8.4 & 0.6 & 49.2 & 57.4 \\
\hline
\end{tabular}

consisted of the electrochemical characterization of the $\mathrm{LiFePO}_{4}$ catholyte suspension to validate the formulation.

Static mode.-A $2 \% \mathrm{LiFePO}_{4}$ - loaded catholyte was firstly prepared (see Table I). This formulation has firstly been tested in static mode (no flow) using the initial reactor. In the same time, a Swagelok cell having a $90 \%$ loaded $\mathrm{LiFePO}_{4}$ composite positive electrode (solid film) like in classical Li-ion batteries has been assembled and tested in the same conditions for sake of comparison.

This way, depending on the amount of suspensions or solid electrodes used, charge and discharge currents were defined in order to have in both cell configurations current densities near $+/-0.5$ mA. $\mathrm{cm}^{-2}$. The results are reported in Figure 2. Note the possibility (Figure $2 \mathrm{a}$ ) of achieving $85 \%$ of the theoretical capacity with a system polarization less than $60 \mathrm{mV}$ for our "initial" flow reactor as

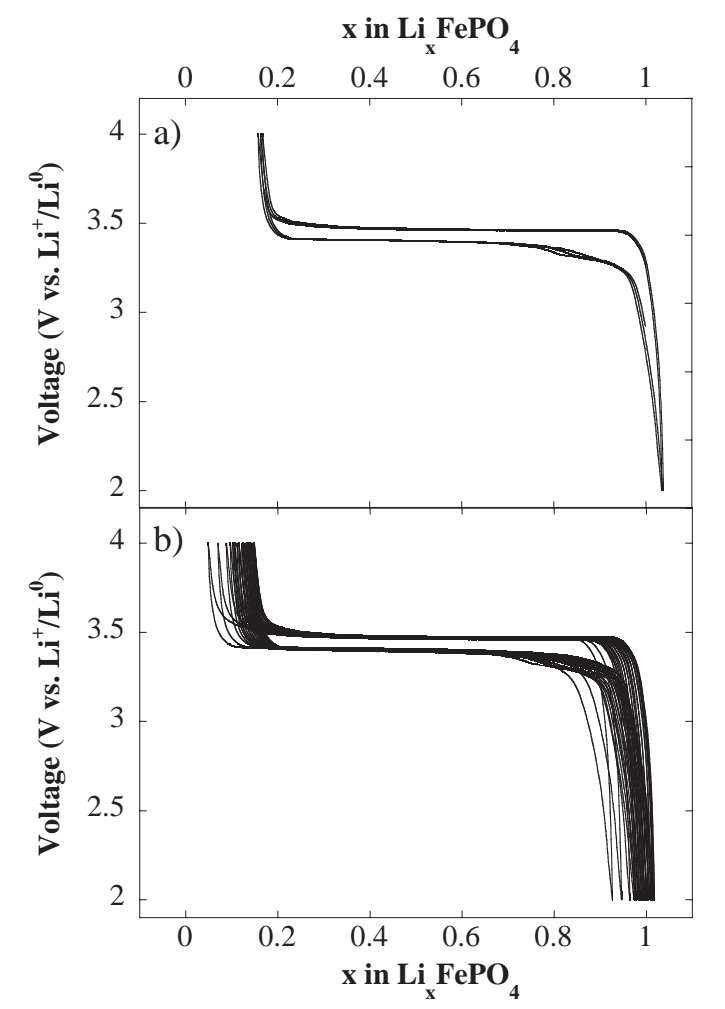

Figure 2. Galvanostatic comparison of the performances of the "initial" reactor (a) versus a conventional Swagelok cell (b) in static modes (no flow). For the former, the positive electrode is made of a $\mathrm{LiFePO}_{4}$ suspension "A" (see Table I) with $\mathrm{Li}$ as the negative electrode. For the latter the negative electrode is still $\mathrm{Li}$, but the positive electrode is a $\mathrm{LiFePO}_{4}$ solid electrode $(90 \%$ of $\mathrm{LiFePO}_{4}+10 \% \mathrm{~KB} 300$ ). In both cases the cells are charged and discharged at $\mathrm{T}=20^{\circ} \mathrm{C}$ with a current density of $0.6 \mathrm{~mA} \cdot \mathrm{cm}^{-2}$. compared to $90 \%$ of material utilization with a polarization of $70 \mathrm{mV}$ in our Swagelok cell (Figure 2b). So, within the accuracy of these experiments it can be concluded that there is no difference in performance between both configurations implying the proper functioning of our solution electrode. This positive result was an impetus to check the behavior of our A solution under constant flow.

Flow mode.-For such tests, we used our non-optimized "initial reactor". More specifically we fixed the flow rate at $31 \mathrm{~mL} \cdot \mathrm{min}^{-1}$ and then performed intermittent galvanostatic cyclings applying 60 minutes oxidation/reduction currents drains separated by a relaxing period of 10 minutes and incremented current densities between subsequent pulses. At this flow rate, it should be noted that this relaxing time largely exceeds the residence time of the particles within the cell. Figure 3 shows the evolution of the cell voltage/current density as a function of both charge and discharge capacities and this when two different incremental current densities of $0.1 \mathrm{~mA} . \mathrm{cm}^{-2}$ (Figure 3a) and $0.5 \mathrm{~mA} . \mathrm{cm}^{-2}$ (Figure 3b) are applied. For the former (Figure 3a)

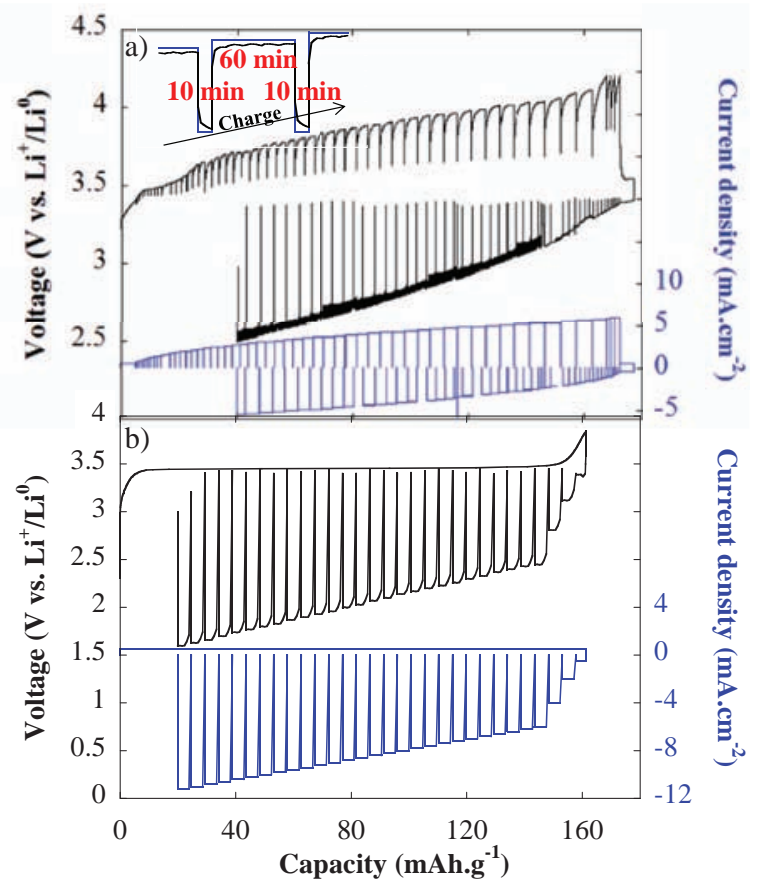

Figure 3. Room temperature galvanostatic charge and discharge at different current densities for two half-electrochemical "initial" cells, containing metallic $\mathrm{Li}$ as the negative and a suspension of $\mathrm{LiFePO}_{4}(\mathrm{~A})$ as the positive electrode. A flow rate of a $31 \mathrm{~mL} \cdot \mathrm{min}^{-1}$ was used in both cases. In a) the current density was increased both in charge and discharge by $0.1 \mathrm{~mA} . \mathrm{cm}^{-2}$ between each pulse while in b) an initial current of $\left(0.5 \mathrm{~mA} . \mathrm{cm}^{-2}\right)$ prior to further increasing the current by $0.5 \mathrm{~mA} . \mathrm{cm}^{-2}$ between each charge and discharge pulse. Inset: detail of one sequence. 


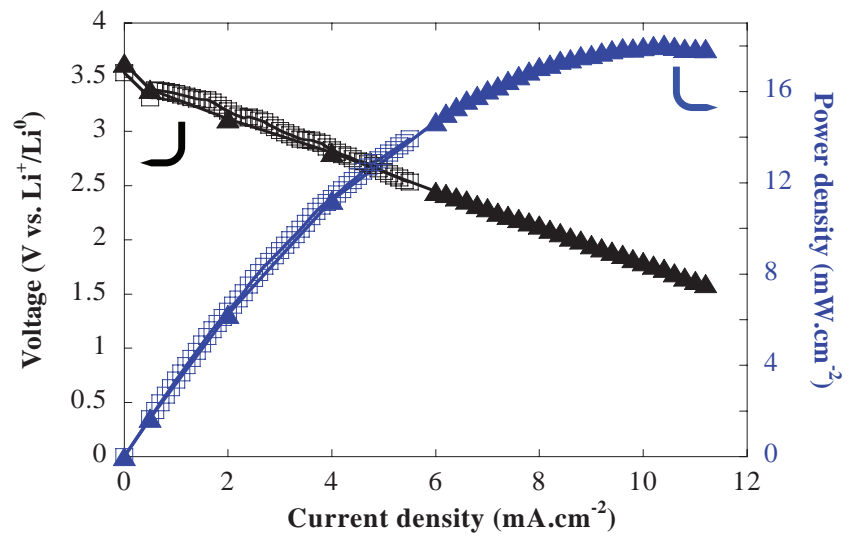

Figure 4. Variation of both the voltage (black) and peak power density (blue) as a function of the current density for the two experiments conducted in Figure 3 with the initial cell reactor. $\Delta \mathrm{V}=\mathrm{f}(\mathrm{i})$ : (black squares), extracted from Fig. 3a; $\Delta \mathrm{V}=\mathrm{f}(\mathrm{i})$ : (black triangles), extracted from Fig. 3b; $\mathrm{PD}=\mathrm{f}(\mathrm{i})$ : (blue squares), extracted from Fig. $3 \mathrm{a} ; \mathrm{PD}=\mathrm{f}(\mathrm{i})$ : (blue triangles), extracted from Fig. 3b.

note that upon the first charge, the current density reaches $6 \mathrm{~mA} . \mathrm{cm}^{-2}$ when the voltage tends to level off at $4.2 \mathrm{~V}$ vs. $\mathrm{Li} / \mathrm{Li}^{+}$(Figure $3 \mathrm{a}$ ). Higher currents were not applied because of the risks of electrolyte oxidation. Using a similar protocol, a cell previously charged at a constant current of $\left(0.5 \mathrm{~mA} \cdot \mathrm{cm}^{-2}\right)$ to $4.0 \mathrm{~V}$ (Figure $\left.3 \mathrm{~b}\right)$ was discharged with a starting current of $-4.5 \mathrm{~mA} . \mathrm{cm}^{-2}$ and an ending one of -11.5 $\mathrm{mA} . \mathrm{cm}^{-2}$ when the voltage reached the $1.6 \mathrm{~V}$ cutoff (Figure $3 \mathrm{~b}$ ). This indicates the feasibility of already achieving decent current densities in non-optimally designed reactors. Last, from the charge and discharge capacities per gram of total catholyte mass within the system, we can deduce an overall conversion approaching nearly $90 \%$ of the theoretical capacity.

Finally, a more elegant way to convey the performance of such a system is to plot both the power density and the cell voltage as function of the current density (Figure 4). Such a plot, commonly used by the fuel cell community, shows that the cell voltage linearly decreases with increasing the current density, while the power density reaches a maximum $\left(18 \mathrm{~mW} . \mathrm{cm}^{-2}\right)$ at around $10.5 \mathrm{~mA} . \mathrm{cm}^{-2}$. For higher discharge rates, the polarization becomes too important to compensate for the gain in current density, hence the drop in power density. Similar performances were measured by Goodenough and co-workers for dissolved hexacyano-ferrates in an aqueous redox-flow system vs. lithium. Such results suggest that the present system does not suffer from mass transfer limitation. In contrast, the linear decrease in the polarization curve (black line in Figure 4) indicates that various ohmic contributions (resistance of the suspension, current collector/particle contact resistance and particle resistance) govern the cell voltage, on this current density interval. This calls for several improvements such as i) a better design of the cell reactor (geometry and else) in order to improve its power performance and ii) a better optimization of the formulation by lowering the amount of conductive additive (KB300) with respect to the amount of active material $\left(\mathrm{LiFePO}_{4}\right)$ as described next.

Optimization of the electrochemical reactor- - In order to improve the aforementioned performances, a new reactor having thinner electrochemical compartments was designed (Figure 1c) and benchmarked with respect to the previous reactor, still using "formulation A" suspension. Figure 5 compares the two cyclic-voltamograms collected on the two reactors using similar sweep rate conditions $\left(5 \mathrm{mV} . \mathrm{s}^{-1}\right)$. Slightly lower overpotentials are observed for the filter-press reactor than for the initial one, with $\mathrm{E}_{\text {peak }}$ at $3.17 \mathrm{~V}$ vs. $\mathrm{Li}^{+} / \mathrm{Li}^{0}(-0.28 \mathrm{~V}$ from equilibrium) and $3.74 \mathrm{~V} \mathrm{vs.} \mathrm{Li}^{+} / \mathrm{Li}^{0}(+0.29 \mathrm{~V}$ from equilibrium $)$ on reduction and oxidation, respectively; $\mathrm{E}_{\text {peak }}$ at $3.14 \mathrm{~V} \mathrm{vs.} \mathrm{Li}^{+} / \mathrm{Li}^{0}$ $(-0.31 \mathrm{~V}$ from equilibrium $)$ and $3.76 \mathrm{vs} . \mathrm{Li}^{+} / \mathrm{Li}^{0}(+0.31 \mathrm{~V}$ from equi-

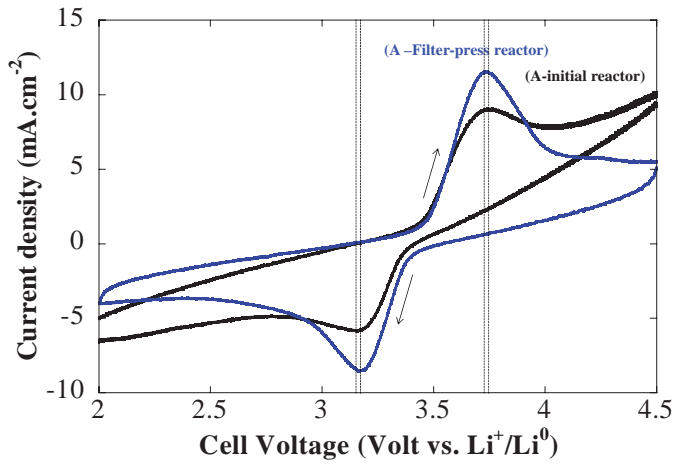

Figure 5. Room temperature comparative voltammograms obtained at a rate of $5 \mathrm{mV} . \mathrm{s}^{-1}$ using the "initial" (black) and "filter-press" (blue) electrochemical cells with the suspension/formulation "A" vs. a metallic Li foil. Dash lines have been used as guides to the reader to highlight the lower overpotentials in charge and discharge resulting from the use of the "filter-press" reactor, as well as the more important peak currents obtained. A flow rate of $12 \mathrm{~mL} \cdot \mathrm{min}^{-1}$ was used.

librium) on reduction and oxidation for the initial, respectively. Such a limited difference is nested in the fact that the resistance increase involved in the thicker catholyte compartment of the initial reactor is partially compensated by the presence of the aluminum foam. Note however the better capability of the press reactor to provide higher current densities (e.g.; amplitude of the current peak) over the same range of flow speed and potential sweep. Last, concerning the charge quantity, despite the fact that the volume (and so the theoretical capacity) of the filter-press reactor is more than 10 times smaller than the initial one $\left(0.4 \mathrm{~cm}^{3}\right.$ vs. $\left.4.5 \mathrm{~cm}^{3}\right)$, its extracted capacity together with its peak current density are bigger.

Optimization of the electrochemical suspension.-Effect of the conductive additive concentration.- Two half RFB "filter-press" cells, using formulation " $A$ " or "B", respectively (see Table I), were charged vs. a $\mathrm{Li}$ counter electrode in a galvanostatic mode at $2 \mathrm{~mA} . \mathrm{cm}^{-2}$ untill the $\mathrm{Li}_{0.5} \mathrm{FePO}_{4}$ composition was reached. The formulation $\mathrm{B}$ contains twice more carbon additive than $\mathrm{A}$. At this stage of charge cyclic voltammetric curves were collected with the appearance of well-defined redox peaks. (Figure 6). The position of the oxidizing and reducing waves shifts toward lower and higher potential, respectively, and their amplitudes increase as the carbon content in the ink is nearly multiplied by two. These results simply indicate that KB300 improves the kinetics of the system as expected. Since KB300 does not

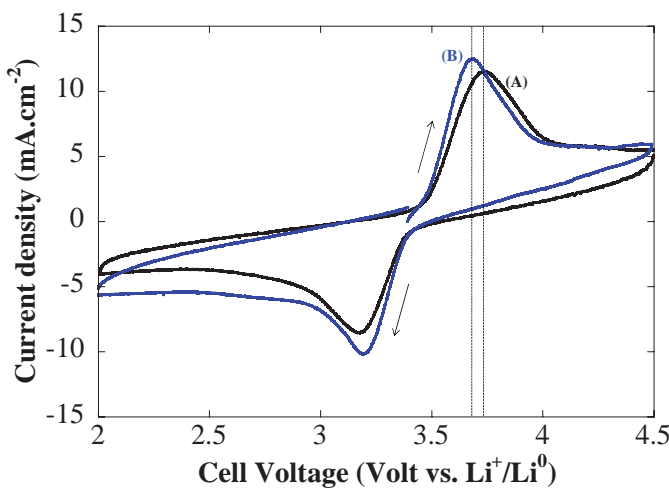

Figure 6. Voltammograms obtained at a rate of $5 \mathrm{mV} \cdot \mathrm{s}^{-1}$ using the "filterpress" electrochemical cell with the suspension/formulations " $\mathrm{A}$ " and " $\mathrm{B}$ " as the positive electrode (curves A and B, respectively) and a metallic Li foil as the negative electrode. Dashed lines are showing the improvement in terms of overpotential (resistance) resulting from the doubled quantity of conductive additive between formulations "A" and "B". A flow rate of $12 \mathrm{~mL} \cdot \mathrm{min}^{-1}$ was used. 
impact the ionic conductivity of the solution, (except slightly through the viscosity), its effect is mainly rooted in the creation of electronic percolation paths (carbon-carbon-particles) in the solution increasing the "effective" surface area of the current conductor, hence leading to a lower resistance and better kinetics. Another side advantage of increasing the solution electronic wiring resides in a shorter traveling distance for Li-ions. This is a good thing as electrons and ions must be simultaneously present to trigger a redox reaction.

Further exploiting these curves by assuming that the observed decrease in the cell voltage (from $290 \mathrm{mV}$ to $230 \mathrm{mV}$ ) at constant current between the two samples is governed by the suspension electrical resistance, several valuable parameters can be deduced for the system using equation 1 . From this equation, which expresses in a general way the $\Delta V$ variation as a function of i) $\rho$ : ionic resistivity of the electrolyte $(\Omega \cdot m)$, ii) S: current collector surface $\left(\mathrm{m}^{2}\right)$, iii) l: equivalent thicknesses (m), and iv) current (A), we can deduce $l$ knowing all other parameters.

$$
\begin{aligned}
\Delta V_{\text {form. }{ }^{\prime \prime} A^{\prime \prime}}-\Delta V_{\text {form. }{ }^{\prime \prime}} & =R_{\text {form. }{ }^{\prime \prime} A^{\prime \prime}} I-R_{\text {form." } B^{\prime \prime}} I \\
& =\rho \times\left(\frac{l_{\text {form." } A^{\prime \prime}}}{S}-\frac{l_{\text {form. }{ }^{\prime \prime} B^{\prime \prime}}}{S}\right) \times I
\end{aligned}
$$

By entering the experimental values of the electrolyte resistivity ( $\rho$ $\left.=1.02 \cdot 10^{-3} \Omega \cdot \mathrm{m}^{10}\right)$, the current density $\left(10 \mathrm{~mA} \cdot \mathrm{cm}^{-2}\right)$ in this equation and taking the surface of the overall current collectors, it could be estimated that the $60 \mathrm{mV}$ drop in cell voltage between samples A and sample $\mathrm{B}$ corresponds to a decrease in the percolating conduction length $\Delta l_{\text {dic }}$ (orthogonal to the electrode surface) equal to 110 $\mu \mathrm{m}$, which corresponds to nearly $11 \%$ of the thickness of the anodic compartment.

To confirm this result, another set of experiments was carried out with various low volumetric percents of KB300, and formulations E1 to E4 were prepared (see Table I). We found that an increase in the KB300 volumetric percent from 3.6 to $4.4 \%$ (formulations E1 to E4) results in a decrease in the cell voltage by about $450 \mathrm{mV}$ at the involved current ranges. Analyzing such results, according to relation (1), leads to a linear variation (slope $=-0.522$ ) of the percolating conduction length $\left(\Delta l_{d i c}\right)$ versus the KB\% vol, confirming the benefit of increasing the amount of KB300 for better kinetics, which does not come as a real surprise (Figure 7a).

Interestingly, using a similar current density, namely $10 \mathrm{~mA} . \mathrm{cm}^{-2}$, a nearly linear evolution trend (slope $=-0.174$ ) of $\Delta l_{d i c}$ vs. $\mathrm{LiFePO}_{4 \% \text { vol. }}$ (Figure 7b) was also found with increasing the volumetric percents of carbon-coated $\mathrm{LiFePO}_{4}$ active material. Nevertheless, to have the same decrease in the cell voltage (about $450 \mathrm{mV}$ ), an increase of $\sim 2.4$ in the vol. percent of $\mathrm{LiFePO}_{4}$ is required, most likely because of the low coverage of the $\mathrm{LiFePO}_{4}$ particles with the graphite coating and the relatively low B.E.T. surface area of the active material versus the one of the conductive additive.

From a simple comparison of the slopes of the two linear relations ( 0.522 vs. 0.174$)$, it can be deduced that for the same volume\% of additive to the suspension, KB300 provides a decrease in the conductivity length about 3 times greater than carbon-coated $\mathrm{LiFePO}_{4}$. Therefore, caution has to be exercised as this factor 3 improvement does not directly translate into the overall electrode performance in terms of capacity/energy density owing to the electrochemical inactivity of KB300. Indeed, a 2-fold increase in the carbon content of the suspensions (formulation A to formulation B) was shown to solely increase the current amplitude from $1.15 .10^{-2} \mathrm{~A} . \mathrm{cm}^{-2}$ to $1.25 .10^{-2}$ A. $\mathrm{cm}^{-2}$ as deduced from cyclic voltammetry. Last, from an integration of such values together with the residence time of the suspension within the reactor $(0.035 \mathrm{~min})$ at the flow rate used and the positive cell electroactive volume $\left(0.4 \mathrm{~cm}^{3}\right)$ we could deduce the conversion ratio for one pass through the reactor as being of $6.0 \%$ and $7.7 \%$ for the formulations A and B, respectively. For sake of completeness, details of the conversion percentage calculation applied to a concrete example are given in Table II. Such a calculation has been used to determine the entire conversion ratio reported hereafter.

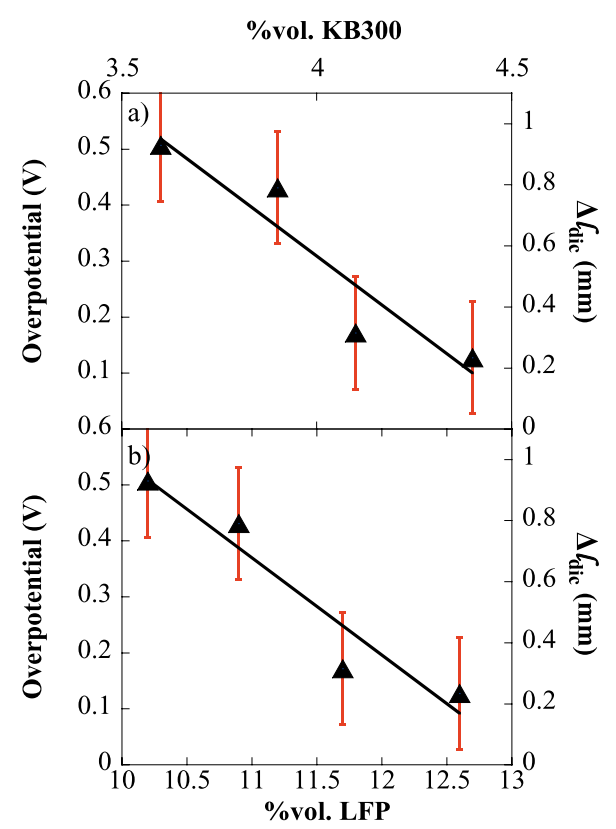

Figure 7. The measured overpotentials and the decrease in the conduction length as a function of the volumetric percent of $\mathrm{KB} 300\left(\Delta \mathrm{l}_{\text {dic }}\right.$ $=2.398-0.522 \times \mathrm{KB} \%$ vol. $\left.\mathrm{R}^{2}=0.94\right)$ in a) and of $\mathrm{LiFePO}_{4}\left(\Delta \mathrm{l}_{\mathrm{dic}}=2.279\right.$ $-0.174 \times \mathrm{LiFePO}_{4 \%}$ vol. $\mathrm{R}^{2}=0.96$ ) in b) for the formulations "E1", "E2", "E3" and "E4" (see Table I). The decrease in the conduction length has been measured using the equation 1 . The slope increase for carbon as opposed to $\mathrm{LiFePO}_{4}$ additives indicates a greater effect of the carbon conducting additive on both the overpotential and conduction length.

Overall, it can be concluded that adjusting the electrode formulation to achieve both high energy density and high kinetics will require a delicate balance between the amounts of $\mathrm{KB} 300, \mathrm{LiFePO}_{4}$ and electrolyte apart from an optimisation of the electrochemical reactor, with the goal being to limit the amount of electrochemically dead carbon. This is along the line of what has long been experienced with solid electrodes for $\mathrm{Li}$-ion batteries.

Effect of the active material concentration.- The effect of the active material content on the RFB "filter-press" cell performances was investigated using formulations " $\mathrm{A}$ " and " $\mathrm{C}$ " containing 2 and $4 \%$ vol. of $\mathrm{LiFePO}_{4}$ together with 9.4 and $9.2 \%$ vol. of $\mathrm{KB} 300$, respectively. A similar testing protocol, as previously described, which consists in the oxidation of the suspension at a current rate of $5 \mathrm{~mA} . \mathrm{cm}^{-2}$ to reach the $\mathrm{Li}_{0.5} \mathrm{FePO}_{4}$ composition prior to collecting cyclo-voltamograms was used and the results are reported in Figure 8.

Bearing in mind that the theoretical capacities of suspensions " $\mathrm{A}$ " and "C" are different by a factor 2; 2.71 and 5.31 mAh.cm" in the $0.4 \mathrm{~cm}^{3}$ of the catholyte volume, respectively, one would expect the corresponding capacity during oxidation and/or reduction to be multiplied by $\approx 2$. Surprisingly, we experimentally observed that the charge capacity for suspension A during one passage ( $0.035 \mathrm{~min}$ ) through the electrochemical interface $\left(0.4 \mathrm{~cm}^{3}\right)$ is $0.163 \mathrm{mAh} . \mathrm{cm}^{-3}$ as compared to $0.76 \mathrm{mAh} . \mathrm{cm}^{-3}$ for suspension "C", which is a factor 4.7 higher (see Table II for details). Moreover, the shift of the position of the oxidation peak $\left(\mathrm{E}_{\text {oxy. }}\right.$ ) from $3.74 \mathrm{vs}$. $3.70 \mathrm{~V}$ when the suspension $\mathrm{C}$ is used is indicative of a better electronic percolation. Thus, the origin of the large increase in capacity when comparing suspension $\mathrm{A}$ and $\mathrm{C}$ is most likely rooted in the enhancement of the electronic percolation pathways within the catholyte provided by the higher mass concentration of carbon-coated $\mathrm{LiFePO}_{4}$ particles, hence enabling their better utilization.

Further testing the effect of increasing active material concentration in terms of kinetics was carried out with suspensions containing increasing amounts of carbon-coated $\mathrm{LiFePO}_{4}$ active material ["E1 to 
Table II. The variation of the second charge and discharge capacities for the "filter-press reactor" using formulation D as a function of the flow rate is listed. Results are extracted from Fig. 10. The conversion percentage represents the proportion of particles oxidized/reduced during their one passage through the reactor. To perform this kind of calculation, residence time is calculated from the flow rate (ex. $\left.12 \mathrm{~mL} . \mathrm{min}^{-1}\right)$ and the catholytic electroactive volume $\left(e x .0 .4 \mathrm{~cm}^{3}\right)$ which implies that the $\mathrm{LiFePO}_{4}$ particles stay in the cell reactor volume for 0.035 min during each passage. Afterwards, the voltammogram $I=f(E)$ is then integrated symmetrically around $E_{p e a k}$ and during this residence time (in this example, the integration is done from $0.0175 \mathrm{~min}$ before to $0.0175 \mathrm{~min}$ after the peak current in the voltammogram.). The quantity of charge obtained by this integration $(0.78 \mathrm{mAh})$ is then divided by the theoretical volumetric capacity of the "D" suspension for the electroactive volume $\left(4.87 \mathrm{mAh} . \mathrm{cm}^{-3}\right.$, i.e. $1.948 \mathrm{mAh}$ for $\left.0.4 \mathrm{~cm}^{-3}\right)$. This gives a $40 \%$ utilization $(e . g ; 0.78 / 1.948)$ of the suspension $(e . g$ $40 \%$ of the particles area converted during one passage).

\begin{tabular}{|c|c|c|c|c|c|}
\hline \multirow[b]{2}{*}{$\begin{array}{c}\Phi \\
\left(\mathrm{cm}^{3} \cdot \mathrm{min}^{-1}\right)\end{array}$} & \multirow[b]{2}{*}{$\begin{array}{l}\text { Residence time } \\
\text { (min) }\end{array}$} & \multicolumn{2}{|c|}{ Oxidation } & \multicolumn{2}{|c|}{ Reduction } \\
\hline & & $\begin{array}{l}\text { Charge quantity per } \\
\text { residence time } \\
(\mathrm{mAh})\end{array}$ & $\begin{array}{l}\text { Conversion per } \\
\text { one passage } \\
(\%)\end{array}$ & $\begin{array}{l}\text { Charge quantity per } \\
\text { residence time } \\
(\mathrm{mAh})\end{array}$ & $\begin{array}{c}\text { Conversion per } \\
\text { one passage } \\
(\%)\end{array}$ \\
\hline 8.33 & 0.050 & 1.19 & 61.1 & 0.86 & 44.1 \\
\hline 12.0 & 0.035 & 0.78 & 40.0 & 0.52 & 26.7 \\
\hline 18.0 & 0.022 & 0.52 & 26.7 & 0.36 & 18.5 \\
\hline 25.0 & 0.018 & 0.44 & 22.6 & 0.31 & 15.9 \\
\hline
\end{tabular}

"E4", see Table I]. We experienced that increasing the concentration of active material from 4.0 to $12.6 \%$ vol. leads to a slight increase in the magnitude of the current as opposed to the large increase previously observed when switching from suspension A $(2.0 \%$ vol. of $\left.\mathrm{LiFePO}_{4}\right)$ to suspension $\mathrm{C}\left(4.0 \%\right.$ vol. of $\left.\mathrm{LiFePO}_{4}\right)$. This means that the $\mathrm{LiFePO}_{4}$ threshold content for the suspension to reach its full electronic percolation is near $4 \%$ vol.

Optimum percolation.- At this stage, from the data obtained for the different $\mathrm{A}, \mathrm{B}$ and $\mathrm{C}$ formulations it can be deduced that electronic percolation is essential for obtaining good performances. Although carbon, as the conductive additive, provides most of the suspension electronic wiring we show that the active $\mathrm{LiFePO}_{4}$ material, via its own carbon coating, has also a noticeable effect. Therefore, the advantage of providing part of the electronic conductivity by adding coated $\mathrm{LiFePO}_{4}$ resides in the fact that we are increasing the suspension energy density while affecting its viscosity less than by adding carbon. In light of such considerations, we have elaborated formulation D (same weight of $\mathrm{LiFePO}_{4}$ with increased carbon additive content) for optimum performances.

We evaluated the performance of this formulation on the "filterpress" cell, using the same experimental protocol as previously described (i.e. oxidation of the suspension at $5 \mathrm{~mA} . \mathrm{cm}^{-2}$ to reach the $\approx \mathrm{Li}_{0.5} \mathrm{FePO}_{4}$ composition). The resulting voltammogram is reported in Figure 9. It shows a peak current as high as $130 \mathrm{~mA} . \mathrm{cm}^{-2}$, which

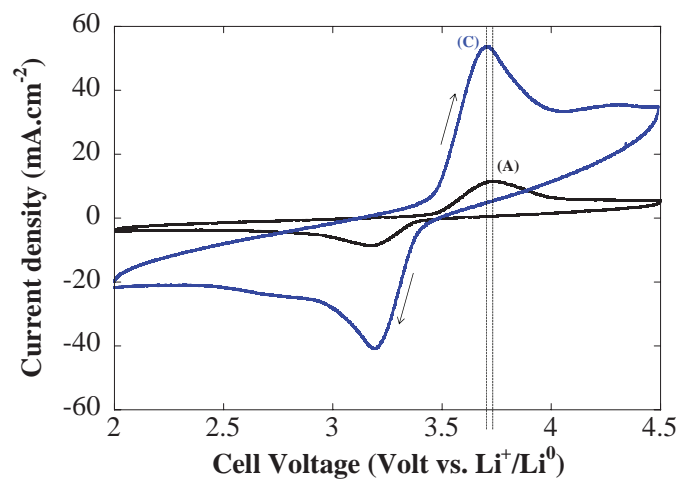

Figure 8. Voltammograms obtained at a rate of $5 \mathrm{mV}^{-\mathrm{s}^{-1}}$ using the "filterpress" electrochemical cell, with the suspensions/formulations "A" and "C" (see Table I) vs. a metallic Li foil. Lines are guide to the readers to highlight improvements in terms of both overpotential (resistance) and peak current $(\approx 5$ times) resulting from the doubled amount of active material between formulations "A" and "C". Flow rates of $12 \mathrm{~mL} \cdot \mathrm{min}^{-1}$ were used. is far exceeding what can be obtained in conventional Li-ion batteries with this material. Integration of this peak current with respect to the suspension passing time in the cell leads to a capacity of $0.78 \mathrm{mAh}$ as compared to the theoretical one of $1.95 \mathrm{mAh}$, which could be expected from our formulation, bearing in mind the electroactive volume of our reactor $\left(0.4 \mathrm{~cm}^{3}\right)$. This simply means that a $40 \%$ conversion ratio on one passage can be achieved through our "filter-press" reactor. A better conversion ratio could be achieved by reducing our reactor volume (e.g. thickness), providing that we can control our suspension viscosity for decent flow. This calls for rheology studies that are being undertaken.

Effect of the flow rate on the current magnitude. - The "D" suspension was selected to perform such a study which basically consists in collecting cyclic-voltammograms at a rate of $5 \mathrm{mV} \cdot \mathrm{s}^{-1}$ (Figure 10) for suspensions flowing through our "filter press" reactor at different flow rates $(\Phi)$. Whatever the values of the flow rate, current densities ranging from 120 to $150 \mathrm{~mA} . \mathrm{cm}^{-2}$ can be achieved. Taking into account the geometrical area of the electroactive $\mathrm{Li}\left(4 \mathrm{~cm}^{2}\right)$, this leads to an overall magnitude of the current ranging from $480 \mathrm{~mA}$ to 600 $\mathrm{mA}$. To put such numbers in perspective we collected, as described in (Figure 3) and using the filter-press cell, the discharge power curve for a "D" formulation flowing at a rate of $25.0 \mathrm{~cm}^{3} \cdot \mathrm{min}^{-1}$ within the reactor. A power density (See Figure 11) as high as $328 \mathrm{~mW} . \mathrm{cm}^{-2}(-104$ mA.cm ${ }^{-2}$ at $\left.3.154 \mathrm{~V} \mathrm{vs.} \mathrm{Li}^{+} / \mathrm{Li}^{0}\right)$ which is twenty times greater than the maximum we have reached with our initial reactor was obtained.

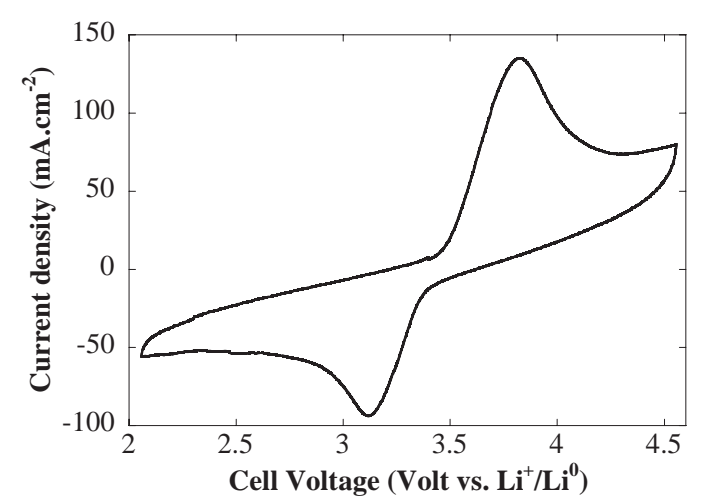

Figure 9. Voltammogram obtained at a rate of $5 \mathrm{mV} . \mathrm{s}^{-1}$ using the "filterpress" electrochemical cell, with the suspension/formulation "D" (see Table I) vs. a metallic $\mathrm{Li}$ foil. Whatever the formulations we have tried this is the highest current density $\left(130 \mathrm{~mA} . \mathrm{cm}^{-2}\right)$ we have ever obtained using a flow rate $=12$ $\mathrm{mL} \cdot \mathrm{min}^{-1}$. 


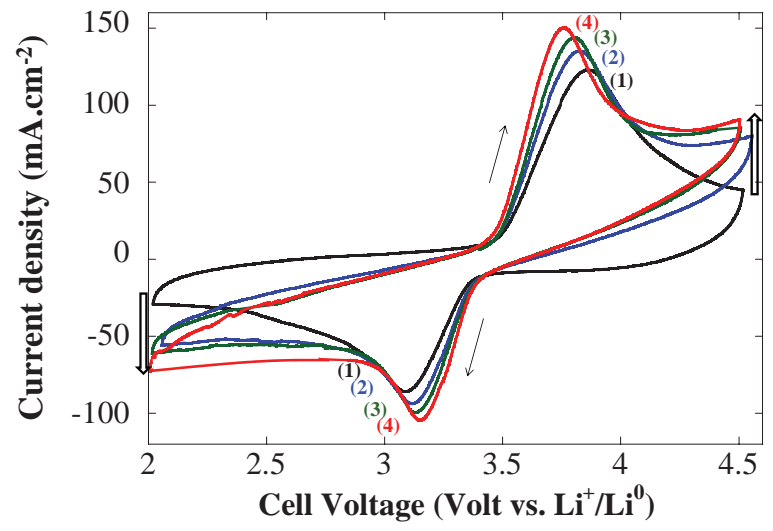

Figure 10. The effect of the suspension flow rate through the "filter-press" electrochemical cell on the shape of the voltamograms collected at a rate of 5 $\mathrm{mV} \cdot \mathrm{s}^{-1}$ is shown with in (1): no flow; and in (2), (3), and (4) a flow rate of $2.0 ; 18.8$; and $25.0 \mathrm{~cm}^{3} \cdot \mathrm{min}^{-1}$, respectively. We have used formulation " $\mathrm{D}$ " for such an experiment. Arrows at the extremities of the voltammogram are pointing the growth of the diffusion wave when the flow rate is increased. Both the overall overpotentials and current densities are growing as well when the flow rate is increased.

Interestingly, the maximum power is reached at high current densities where the diffusion limitation occurs, that confirms the improvement of the ohmic behavior of the system thanks to the new reactor design.

Further exploiting the evolution of the cyclic-voltammograms traces as a function of the flow rate (Figure 10) reveals interesting features with namely the presence at no flow $\left(\Phi=0 \mathrm{~cm}^{3} \cdot \mathrm{min}^{-1}\right)$ of potential peaks both on the cathodic and anodic sides, implying a concentration depletion in the electroactive area. These peaks are becoming less pronounced when the flow rate increases, with the apparition of a diffusion wave (see arrow on Figure 10) meaning that the electroactive area/contact with an electronic conductor is supplied by a slightly more constant flux. Such an effect can be analyzed using Leveque's relationship expressing Sherwood number as a function of both Reynolds and Schmidt numbers (Eq. 1 in the Annex ${ }^{11}$ ), and more specifically by examining the flow rate dependence on the current [2]:

$$
I_{\lim }=n \times F \times S \times C^{*} \times \text { cste } \times \Phi^{a}
$$

We plotted the magnitude of the current either in a normal (Figure 12a) or logarithmic scale (Figure 12b) as a function of the flow rate. Both plots seem to indicate a linear evolution with the logarithmic plot giving a better correlation coefficient ( 0.999 vs. 0.987 for $I_{\text {anod }}$ ). The empiric relationship obtained via these plots (see figure description) enables to extract a value of $\sim 0.1$ for the exponent $\alpha$.

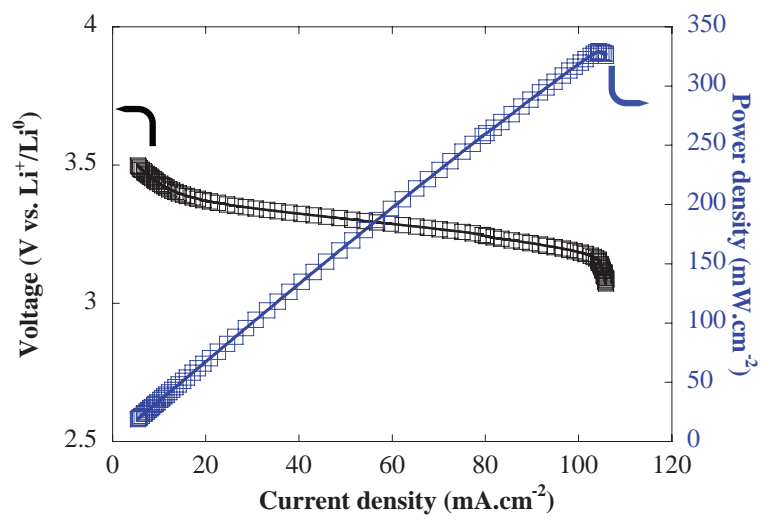

Figure 11. The peak power curve is shown for a "filter-press" electrochemical cell using i) the suspension/formulation " $D$ " as the positive electrode and ii) metallic $\mathrm{Li}$ as the negative electrode. A flow rate of $25.0 \mathrm{~cm}^{3} \cdot \mathrm{min}^{-1}$ was used.

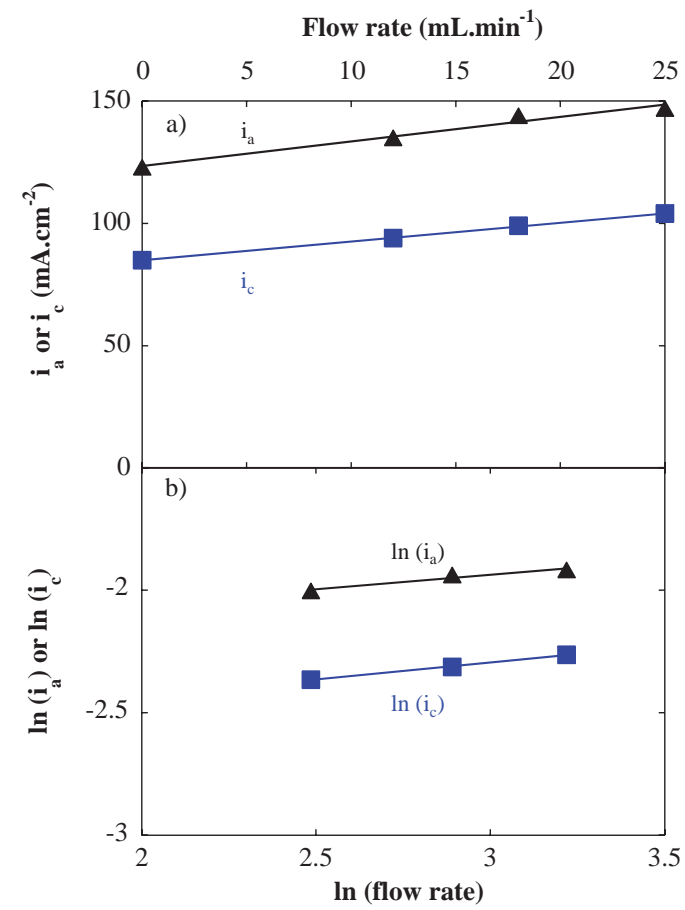

Figure 12. Dependence of the peak current density as a function of the flow rate for the "filter-press" reactor using the formulation " $D$ " (see Table I). Linearity is verified as well for the raw values a) $i$ vs. $f$ (flow rate): ( $i_{\text {anod. }}$ $=0.001 * \Phi+0.123 ; \mathrm{R}^{2}=0.987$ and $\mathrm{i}_{\text {cathod. }}=0.0007 * \Phi+0.085$; $\left.\mathrm{R}^{2}=0.999\right)$ as for the logarithmic values, b) $\ln (\mathrm{i})$ vs. $\ln$ (flow rate): (lni ${ }_{\text {anod. }}$ $=0.117 * \ln \Phi-2.289 ; \mathrm{R}^{2}=0.999$ and $\operatorname{lni} \mathrm{i}_{\text {cathod. }}=0.137 * \ln \Phi-2.707 ; \mathrm{R}^{2}$ $=0.999)$. Results extracted from Figure 10 .

Such a value, based on previous literature reports on similar systems, confirms the relatively low influence of the flow rate on the magnitude of the current, as already deduced from Figure 10.

Turning back to Figure 10 it is also worth mentioning that with increasing the flow rate the polarization decreases (e.g. oxidation and reduction peaks shift toward lower and higher potentials, respectively) while the peak current amplitude increases. At first, these results are somewhat intuitive since fast flow rates should i) enable greater quantities of active material to pass through the reactor and ii) simultaneously increase the shocks between particles with for consequence a decrease in the ionic diffusion and electronic percolation lengths which should lead to a lower polarization as observed.

To quantify this aspect and get further insight into the decrease in the current at 'low flows', (See Table II) we attempted to evaluate the conversion ratio for one passage through the reactor. This evaluation was performed as follows. The average residence time of the suspension in the reactor was first evaluated, for the different flow rates that we have tried, taking into account the volume $\left(0.4 \mathrm{~cm}^{3}\right)$ of our positive polarity compartment. Then, the full theoretical volume capacity for $100 \%$ conversion was calculated. For instance, with solution D, such a theoretical volumetric capacity is estimated to $1.95 \mathrm{mAh}$. The conversion rates, obtained for various flow rates during the currentpotential curve, for 'one residence time' are reported in Table II, and they are found to decrease with increasing the flow rate, confirming our intuition. Their values are found to range from 15 to $60 \%$, which is quite reasonable concerning particles flowing in suspension with no "forced" electronic contact between active material and current collector and free ionic pathways between metallic $\mathrm{Li}$ and active material. Last the noted differences between oxidation and reduction charge quantities, solely observed during cyclic-voltammetry measurements are still not fully explained also we privileged at the present time some electrolyte oxidation owing to the fact that we pushed the oxidation to voltages as high as $4.5 \mathrm{~V}$. 
So overall, this result tends to give preference to the intermittent flow-mode suggested by Duduta et al. ${ }^{8}$ in order to obtain high conversion rates (close to a classical battery). At the scale of the system, high flow is however better to increase energetic efficiency (Voltage difference between charge and discharge) and the global amount of charge. This insight will help in designing new capable experimental protocol to better take advantage of the flow parameter in conjunction with the thickness vs. the surface of the core reactor.

\section{Conclusions}

We have reported a survey on the effect of various experimental physical-chemical parameters (cell design, suspensions formulations, flow rates, and so on) on the performances of the $\mathrm{LiFePO}_{4} / \mathrm{C}$ redox flow system. We demonstrated the importance of the cell design to ensure a better flow distribution contact between the suspension and the current collector. The use of Al foams within our "initial" cell compartment or the decrease in its thickness was meant for such a purpose, but there is still room for improvements. Additionally, we found that mastering the electrolyte formulation is quite tricky, as compared to solid state electrodes, owing to the need to add an extra dimension that is the control of the viscosity/rheology of the suspension.

Besides, we showed by changing the flow rate the feasibility of improving the migration/diffusion for the involved active material concentrations (i.e. $\mathrm{Li}^{+}$). An empiric 'logarithmic' relationship between the magnitude of the peak current and the flow rate has been found, enabling to access the expression of the mass transfer evolution versus flow (using the Leveque relationship) and expressed as $k=$ cste $\times \Phi^{0.1}$.

Last, specific conditions were chosen in this study to plot current potential curves (i.e. relatively low flow rate and relatively high potential scan rate $\left(5 \mathrm{mV} . \mathrm{s}^{-1}\right)$ giving high conversion (up to $60 \%$ ) for one pass through the reactor. We found that decreasing the feed flow, and recycling the solution, enables to increase both apparent mass transfer coefficient and conversion of the electroactive material, leading to $90 \%$ global conversion. It therefore remains that several modifications are being pursued to improve the overall energy balance (cell production - pump consumption), like the nature of the separator, the size and the surface of the active material particles, the nature of the electrolyte, the configuration of the cathode compartment, as well as the coupling of several reactors in serial, or working with an intermittent pumping system.

Overall, by acting both on the cell design and catholyte formulations, power densities of $328 \mathrm{~mW} . \mathrm{cm}^{-2}$, far larger than the ones measured in high-rate battery-electrodes and mid-way to fuel cells (1 W. $\mathrm{cm}^{-2}$ ), were obtained. By increasing the volumetric percentage of active material to $12.6 \%$ vol., suspensions having energy densities of $50 \mathrm{Wh} . \mathrm{kg}^{-1}$ (67 Wh.L $\left.{ }^{-1}\right)$ were obtained, similar to what is achieved in the best industrial All-Vanadium Redox-Flow batteries. To get pass such a limit, suspensions having $20 \%$ vol. or more of active materials will be required providing that we can maintain a workable viscosity. This is not an insurmountable task as using such type of inks is common practice in various ink-printing technologies, and we have a lot to learn from such a community we are presently collaborating with.

\section{Acknowledgments}

The authors thank J-P. Bonnet for conducting the viscosity measurements, Dr. B. Lestriez, Dr. D. Guyomard, Dr. M. Cerbellaud and Dr. Youssry Abdelnaby from the IMN/Universite de Nantes for the fruitful discussions, as well as Pr. P. Barboux, Dr. Giaume and Dr. C. Laberty from UPMC/Chimie Paristech.

\section{List of Symbols}

LFP $\quad \mathrm{LiFePO}_{4}$ solid cathode material

Csp Carbon "Super P" carbon black conductive additive KB/KB300 Ketjen Black EC-300 J carbon conductive additive

LP30 Ethylene Carbonate/Dimethyl Carbonate (1:1) $)_{\mathrm{vol}}$ and $\mathrm{LiPF}_{6}(1 \mathrm{M})$ electrolyte

$\rho \quad$ Ionic resistivity of the electrolyte ( $\Omega . \mathrm{m})$

$\mathrm{S} \quad$ Current collector surface $\left(\mathrm{m}^{2}\right)$

$l \quad$ Characteristic length e.g. thickness of the flow channel $(\mathrm{m})$

I Current (A)

k Mass transfer coefficient $(\mathrm{m} / \mathrm{s})$

$\mathrm{d}_{\mathrm{e}} \quad$ Equivalent / Hydraulic diameter (m)

D Diffusion coefficient $\left(\mathrm{m}^{2} / \mathrm{s}\right)$

$\mathrm{a}, \mathrm{a}^{\prime}$ and $\alpha \quad$ Constants

$\mathrm{u}$

$v$

Average velocity of the fluid $(\mathrm{m} / \mathrm{s})$

Kinematic viscosity $\left(\mathrm{m}^{2} / \mathrm{s}\right)$

\section{References}

1. A. Z. Weber, M. M. Mench, J. P. Meyers, P. N. Ross, J. T. Gostick, and Q. Liu, J. Appl. Electrochem., 41, 1137 (2011).

2. C. Ponce de Leon, A. Frıas-Ferrer, J. Gonzalez-Garcıa, D. A. Szanto, and F. C. Walsh, J. of Power Sources, 160, 716 (2006).

3. Y.-M. Chiang, W. C. Carter, B. Y. Ho, and M. Duduta, World Patent, WO2009151639.

4. Y.-M. Chiang and C. W. Carter, US Patent, US20100047671.

5. Y.-M. Chiang and C. W. Carter, US Patent, US2011200848.

6. Y.-M. Chiang and C. W. Carter, World Patent, WO2011084649.

7. Y.-M. Chiang and R. Bazarella, World Patent, WO2010118060.

8. M. Duduta, B. Ho, V. C. Wood, P. Limthongkul, V. E. Brunini, W. C. Carter, and Y.-M. Chiang, Adv. Energy Mater., 1, 511 (2011).

9. Y. Lu and J. B. Goodenough, J. Mater. Chem., 21, 10113 (2011)

10. D. Djian et al., Journal of Power Sources, 172(1), 416 (2007).

11. See supplementary material at http://dx.doi.org/10.1149/2.071208jes.html. 